\title{
Diatom flux reflects water-mass conditions on the southern Northwind Abyssal Plain, Arctic Ocean
}

\author{
J. Onodera ${ }^{1}$, E. Watanabe $^{1}$, N. Harada ${ }^{1}$, and M. C. Honda ${ }^{2}$ \\ ${ }^{1}$ Research and Development Center for Global Change, Japan Agency for Marine-Earth Science \\ and Technology, Natsushima-cho 2-15, Yokosuka 237-0061, Japan \\ ${ }^{2}$ Department of Environmental Geochemical Cycle Research, Japan Agency for Marine-Earth Science and \\ Technology, Natsushima-cho 2-15, Yokosuka 237-0061, Japan \\ Correspondence to: J. Onodera (onoderaj@jamstec.go.jp)
}

Received: 1 September 2014 - Published in Biogeosciences Discuss.: 30 October 2014

Revised: 19 January 2015 - Accepted: 11 February 2015 - Published: 4 March 2015

\begin{abstract}
We studied time-series fluxes of diatom particles from 4 October 2010 to 18 September 2012 using bottomtethered moorings with two sediment traps deployed at 180 and $1300 \mathrm{~m}$ depths at Station NAP $\left(75^{\circ} \mathrm{N}, 162^{\circ} \mathrm{W} ; 1975 \mathrm{~m}\right.$ water depth) in the western Arctic Ocean. This paper discusses on the relationship of time-series diatom fluxes to satellite-based sea-ice motion and simulated hydrographic variations. We observed clear maxima of the diatom valve flux in November-December of both 2010 and 2011, and in August 2011. Diatoms in samples were categorized into 98 taxa. The diatom flux maxima were characterized by many resting spores in November-December and by the sea-iceassociated diatom Fossula arctica in August 2011. These assemblages along with abundant clay minerals in the samples suggest a significant influence of shelf-origin materials transported by mesoscale eddies, which developed along the Chukchi Sea shelf break. In contrast, the fluxes of total mass and diatoms were reduced in summer 2012. We hypothesize that this suppression reflects the influx of oligotrophic water originating from the central Canada Basin. A physical oceanographic model demonstrated that oligotrophic surface water from the Beaufort Gyre was supplied to Station NAP from December 2011 to the early half of 2012.
\end{abstract}

\section{Introduction}

There are numerous studies reporting the significant influence of the recent declining trend in Arctic sea-ice extent (Stroeve et al., 2012) on marine ecosystems (i.e., Grebmeier et al., 2010; Wassmann and Reigstad, 2011; Wassmann et al., 2011). Interannual monitoring to observe the influences of hydrographic variations on primary productivity and the microplankton assemblage is key to estimating the future direction of lower-trophic levels of marine ecosystems and biogeochemical cycles in the Arctic Ocean. In the Canada Basin of the western Arctic Ocean, the shift in wind patterns has promoted downward Ekman pumping and consequent Beaufort Gyre circulation seen in recent decades (McPhee, 2013). The intensification of sea-surface circulation is accompanied by shelf-break upwelling along the southern part of the Beaufort Gyre and by lateral shelf-basin interactions (McLaughlin and Carmack, 2010; Nishino et al., 2011b, 2013; Watanabe and Hasumi, 2009), which also influence ecosystems and biogeochemical cycles. In addition, the enhanced Ekman forcing under decreasing sea-ice cover results in deepening of the nutricline in the central part of the Beaufort Gyre (McLaughlin and Carmack, 2010; Nishino et al., 2011a), limiting the biological pump effect in this area (Nishino et al., 2011a).

Although the shelf and shelf slope areas of the Arctic Ocean have been extensively monitored (i.e., Hargrave et al., 1989; Fukuchi et al., 1993; Wassmann et al., 2004; Forest et al., 2007, 2011; Gaye et al., 2007; Sampei et al., 2011), yearround studies of sinking biogenic particles over the basins are still limited, with a few exceptions (Fahl and Nöthig, 2007; Lalande et al., 2009; Honjo et al., 2010; O’Brien et al., 2013). In the cryopelagic Canada Basin, where picoplankton are the major primary producers, biogenic particles are remineralized in the upper water column, and particulate organic car- 
bon (POC) supplied to the deep sea is essentially composed of allochthonous old carbon (Honjo et al., 2010). The low production of shell-bearing microplankton and zooplankton fecal pellets, which have roles as ballast for sinking organic matter, limits the function of the biological pump in the oligotrophic cryopelagic Canada Basin (Honjo et al., 2010).

A long-term sediment trap experiment, including the observation of diatom fluxes, was performed in the eastern Fram Strait from 2000 to 2005 (Bauerfeind et al., 2009). Results from the Hausgarten Arctic long-term observatory show that the interannual variations in sea-surface hydrography, including ice conditions, affect the time-series variations in settling particle fluxes and the assemblages of settling plankton remains (Bauerfeind et al., 2009). The only previous report concerning an annual time series of diatom fluxes in the Arctic Ocean basin is that by Zernova et al. (2000), whose target region was at Station LOMO2 off the Laptev Sea. Zernova et al. (2000) showed that there was high diatom production and high settling fluxes of diatom particles under sea ice at Station LOMO2 during the seasonal solar radiation maximum. Lalande et al. (2014) compared short-term monitoring data for diatom fluxes in the Laptev Sea in 1995, the Fram Strait in 1997, and the central Arctic Ocean in 2012. They suggested that nutrient supply is the key factor determining summer diatom production and POC flux in the central Arctic Basin.

In 1998 in the Chukchi Borderland, the ice-tethered drifting sediment trap "S97-120 m" was deployed, recording a relatively high POC flux as compared to that in the Canada Basin (Honjo et al., 2010). Based on the first year-round monitoring of settling particle flux at Station NAP in the southern Northwind Abyssal Plain, Watanabe et al. (2014) suggested that the large amounts of settling biogenic and lithogenic particles in November-December 2010 were transported from the Chukchi Sea shelf by the westward advection of a cold eddy that developed off Barrow Canyon in early summer 2010. According to a schematic diagram in Honjo et al. (2010), the POC fluxes at around $120 \mathrm{~m}$ depth at $75^{\circ} \mathrm{N}$ and around $200 \mathrm{~m}$ at $80^{\circ} \mathrm{N}$ in the Canada Basin are about 0.12 and $0.08 \mathrm{~g} \mathrm{C} \mathrm{m}^{-2} \mathrm{yr}^{-1}$, respectively (values extracted from their Fig. 11). The annual POC flux at Station NAP during the first deployment period was about 0.24 and $0.32 \mathrm{~g} \mathrm{C} \mathrm{m}^{-2} \mathrm{yr}^{-1}$ at the depths of the shallow and deep traps, respectively (Watanabe et al., 2014).

Diatom dominances in phytoplankton assemblages are usually observed in eutrophic waters, whereas dominance of flagellates and picoplankton rather than diatoms are observed in oligotrophic waters such as central basin (Ardyna et al., 2011; Coupel et al., 2012; Lalande et al., 2014). Diatoms are one of the dominant phytoplankton in the Chukchi Sea (Sukhanova et al., 2009; Coupel et al., 2012; Joo et al., 2012; Laney and Sosik, 2014), and the recent environmental changes have influenced the diatom flora and phytoplankton phenology (Arrigo et al., 2012; Ardyna et al., 2014). As one of the major contributors to the biological pump, settling diatom fluxes in the offshore regions along the Chukchi Sea shelf are likely affected by the recent dramatic environmental changes.

In this paper, we present new findings on the settling flux of diatom valves and the relationships between diatom valve flux, sinking diatom flora, and upper water-mass properties in the southern Northwind Abyssal Plain from October 2010 to September 2012. The Chukchi Sea is one of the obvious areas of retreating summer sea ice (Stroeve et al., 2012). The upper water column in the Chukchi Borderland can be affected by three characteristic water masses: Pacific water, East Siberian Shelf water, and Beaufort Gyre water (Nishino et al., 2011a). Watanabe et al. (2014) documented the eddyinduced winter maximum of settling particle flux at Station NAP. This early-winter event should be observed in settling diatom flux. This paper makes new mention of the summer flux of settling diatom particles in addition to winter flux maximum event of diatom flux. The present paper is the first report on year-round diatom floral flux after the clear trend of declining sea ice in the western Arctic Ocean. We expect that the recent hydrographic changes in the western Arctic Ocean will be reflected in the settling diatom flux and associated assemblages. The objectives of this paper are (1) to report the variation in diatom flux and assemblage and (2) to consider how hydrographic changes in the upper water column are reflected in the diatom assemblage and diatom flux in the Northwind Abyssal Plain.

\section{Materials and methods}

Two year-round deployments of a bottom-tethered mooring with two conical time-series sediment traps (model SMD26S-6000; Nichiyu Giken Kogyo Co. Ltd., Tokyo, Japan) were conducted at Station NAP on the southern Northwind Abyssal Plain $\left(75^{\circ} \mathrm{N}, 162^{\circ} \mathrm{W} ; 1975 \mathrm{~m}\right.$ water depth) from 4 October 2010 through 27 September 2011 and from 4 October 2011 through 17 September 2012. A sediment trap with pressure and temperature sensors was deployed at shallow depth (about 180-260 m) and deep depth (1300-1360 m). The settling particles were collected for 1015 days per sample. Before sediment-trap deployment, the 26 sampling cups of each trap were filled with seawater containing $5 \%$ neutralized formalin as an antiseptic $(\mathrm{pH} \sim 8.2)$. In this study we analyzed the samples from both traps except the one that contained a very low volume of trapped particles.

The recovered sediment-trap samples were sieved through a $1 \mathrm{~mm}$ mesh to remove swimmers (Matsuno et al., 2014), and then the fine size fraction (less than $1 \mathrm{~mm}$ ) was split into appropriate aliquots (1/1000) for diatom analysis by using a wet sample divider (WSD-10; McLane Research Laboratories, East Falmouth, Massachusetts, USA). One of the aliquots was filtered onto a membrane filter $(0.45 \mu \mathrm{m}$ pore size) with a $3 \mathrm{~mm}$ grid. The sample was desalted by rinsing with Milli-Q water, and then the sample filter was dried overnight in an oven at $50^{\circ} \mathrm{C}$. Two sample filters were 


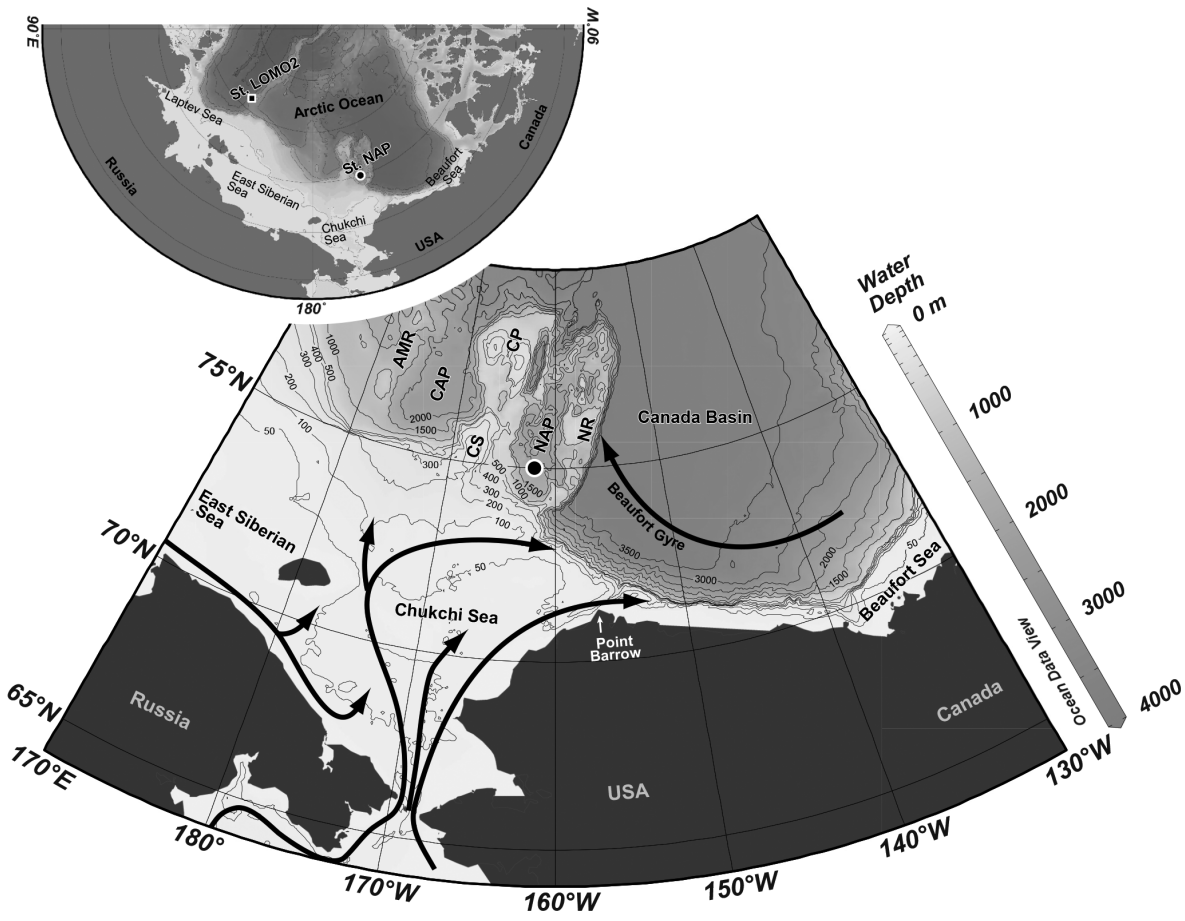

Figure 1. Bathymetric map around Station NAP (solid black circle at $75^{\circ} \mathrm{N}, 162^{\circ} \mathrm{W}$ ) in the western Arctic Ocean, and schematic of seasurface circulation over the Chukchi Sea shelf and in the southern Canada Basin (Danielson et al., 2011). NR, Northwind Ridge; NAP, Northwind Abyssal Plain; CP, Chukchi Plateau; CS, Chukchi Spur; CAP, Chukchi Abyssal Plain; AMR, Alpha-Mendeleev Ridge complex.

prepared for each sample, and then one of the filters was mounted on a microscope glass slide with Canada balsam.

Sample filters mounted on the glass slides were counted for diatoms under a light microscope at $600 \times$ magnification. A duplicate sample was observed using scanning electron microscope observation after osmium coating. A minimum of 400 diatom valves (including resting-spore valves) per sample were identified, usually to species or genus level. As described in a previous microplankton flux study in the southeastern Beaufort Sea (Forest et al., 2007), the flux of diatom-derived POC (hereafter diatom POC flux) was estimated on the basis of diatom cell size and an equation for converting cell volume to carbon content per diatom cell (Menden-Deuer and Lessard, 2000). Diatom valve fluxes were estimated on the basis of valve count numbers, aliquot size, filtered area $\left(535 \mathrm{~mm}^{2}\right)$, area of sample filter observed, aperture area of sediment trap $\left(0.5 \mathrm{~m}^{2}\right)$, and the sampling period (Onodera et al., 2005). The method for bulk component analysis is described by Watanabe et al. (2014).

Sea-ice concentration and light intensity close to Station NAP during the sampling period were obtained from the National Centers for Environmental Prediction (NCEP)/Climate Forecast System Reanalysis (CFSR) (Saha et al., 2010). Seasurface temperature (SST) at Station NAP was taken from the National Oceanographic and Atmospheric Administration (NOAA) OI SST v2 (Reynolds et al., 2002). Because the moored sediment trap array at Station NAP did not include equipment to measure current velocity or salinity, satellitebased sea-ice motion data and numerical simulation results from a physical oceanographic model known as the Center for Climate System Research Ocean Component Model (COCO) (Hasumi, 2006) were applied to estimate the sea ice and ocean current conditions in the western Arctic Ocean during the sampling period. The National Snow and Ice Data Center (NSIDC) provided the Polar Pathfinder $25 \mathrm{~km}$ EASEGrid sea-ice motion vectors, version 2 (Fowler et al., 2013). This data set was constructed from multiple satellite sensors, such as Special Sensor Microwave/Imager (SSM/I), Advanced Microwave Scanning Radiometer - Earth Observing System (AMSR-E), and Advanced Very High Resolution Radiometer (AVHRR), and in situ measurements of the International Arctic Buoy Programme (IABP). In our study, the monthly mean vector data were downloaded from the NSIDC website (http://nsidc.org/data/docs/daac/nsidc0116 icemotion.gd.html). The pan-Arctic ice-ocean model has the horizontal grid size of about $25 \mathrm{~km}$ and 28 vertical levels, where the layer thickness varies from $2 \mathrm{~m}$ in the uppermost level to $500 \mathrm{~m}$ below $1000 \mathrm{~m}$ depth. The sea-ice part includes a one-layer thermodynamic formulation (Bitz and Lipscomb, 1999) and elastic-viscous-plastic rheology (Hunke and Dukowicz, 1997). The ocean component is a free-surface ocean general circulation model formulated with the uniformly third-order polynomial interpolation algorithm (Leonard et al., 1994) for horizontal advection scheme. The 
model domain contains the entire Arctic Ocean; the Greenland, Iceland, and Norwegian seas; and the northern part of the North Atlantic. The spin-up experiment was initiated from the temperature and salinity fields of Polar Science Center Hydrographic Climatology version 3.0 (Steele et al., 2001), no ocean circulation, and no sea ice. The interannual experiment from 1979 to 2012 was then performed. Whereas most parts of experimental designs were the same as in Watanabe (2013) and Watanabe and Ogi (2013), the model version was upgraded from COCO 3.4 to 4.9 and the atmospheric forcing data set was changed from NCEP1 (Kalnay et al., 1996) to the NCEP/CFSR in the present study.

\section{Results}

\subsection{Oceanographic features and mooring conditions}

Station NAP is located at the southwestern edge of the Beaufort Gyre (Fig. 1), and is occasionally influenced by relatively oligotrophic waters of the Beaufort Gyre (Nishino et al., 2011a). The study area is in polar night from early November through early February (Fig. 2a). The CFSR shortwave radiation at the sea surface (or surface of sea ice) ranged from 0 to $378 \mathrm{Wm}^{-2}$ (Fig. 2a). Station NAP is located in a seasonal sea-ice zone, and is covered by sea ice from late October through July (Fig. 2b). Sea surface temperature temporarily increased to about $2{ }^{\circ} \mathrm{C}$ in early August in 2011 and 2012 (Fig. 2d).

The upper water column around the study area is categorized by four water masses (McLaughlin et al., 2011). Under the surface mixed layer (about the upper $25 \mathrm{~m}$ ), Pacific summer water is observed at $25-100 \mathrm{~m}$ water depth (salinity approximately 31-32; Steele et al., 2004). Cold Pacific winter water (temperature minimum at $150 \mathrm{~m}$, salinity around 33; Coachman and Barnes, 1961) is found under the Pacific summer water (100-250 m water depth). Higher salinity water originating from the Atlantic Ocean is observed under the Pacific winter water.

According to the logged data from pressure and temperature sensors attached to the sediment traps, the shallower sediment trap was moored at a water depth of 181-218 m (median, $184 \mathrm{~m}$ ) for the first deployment period, and at 247$319 \mathrm{~m}$ (median, $256 \mathrm{~m}$ ) for the second (Fig. 2c). Therefore, the shallow trap was in Pacific winter water during the sampling period, except for in May and July 2012 (Fig. 2c, d). In July 2012, the depth of the shallower trap deepened to $320 \mathrm{~m}$ in the warm Atlantic water layer, probably because of intensified water currents and incline of mooring, which might have temporarily decreased the trapping efficiency for sinking particles (Matsuno et al., 2014). Although the deepening of shallow trap in May 2012 was minor compared to that in July 2012, the increase in water temperature at shallow-trap depth suggests the shallowing upper boundary of the Atlantic

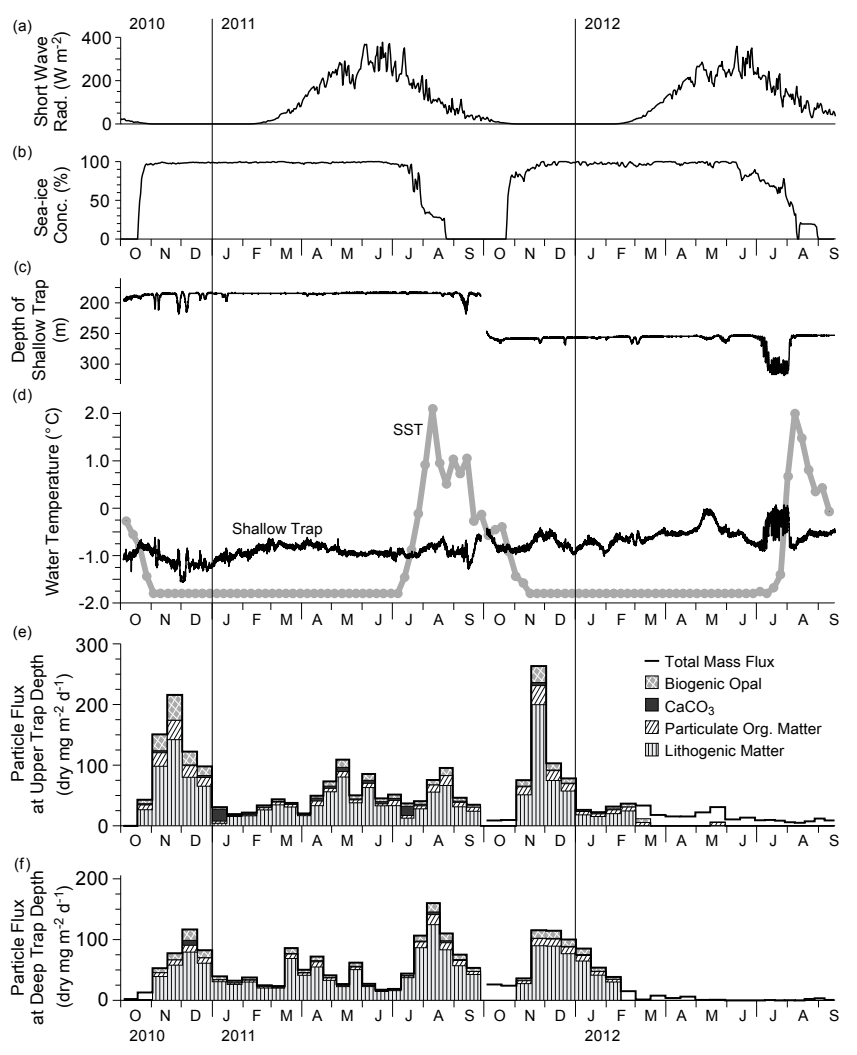

Figure 2. Time-series data at Station NAP from 1 October 2010 through 18 September 2012. (a) Climate Forecast System Reanalysis (CFSR) reanalysis data of shortwave radiation; (b) CFSR reanalysis data of sea-ice concentration; (c) depth log of moored shallow trap, (d) water temperature recorded at moored shallow trap (black line), and NOAA OI.v2 weekly sea-surface temperature at Station NAP (gray line); (e) total mass flux and bulk components of sinking particles at shallow-trap depth (data period was expanded from Watanabe et al., 2014); and (f) total mass flux and bulk components at deep-trap depth. Blank areas in bulk component data indicate no analysis because of limited sample volume.

water layer. The deeper sediment trap was moored at 1318$1378 \mathrm{~m}$ for the entire sampling period.

\subsection{Total mass flux and bulk components}

As previously reported by Watanabe et al. (2014), the total mass flux showed clear annual maxima in NovemberDecember in both 2010 and 2011 (Fig. 2e, f). The major component of trapped particles was lithogenic silt-clay minerals (Fig. 2e). There was another peak in total mass flux in summer 2011, but this summer peak did not appear in 2012. The time series of biogenic opal flux showed variations similar to those of total mass flux ( $r=0.93$ for shallow-trap data, $n=34$; Fig. 2e). Microscopic observation suggests that the biogenic opal in the studied material consisted mainly of diatom valves and radiolarian shells (Ikenoue et al., 2014). The trap samples also contained low numbers of silicoflagellate 

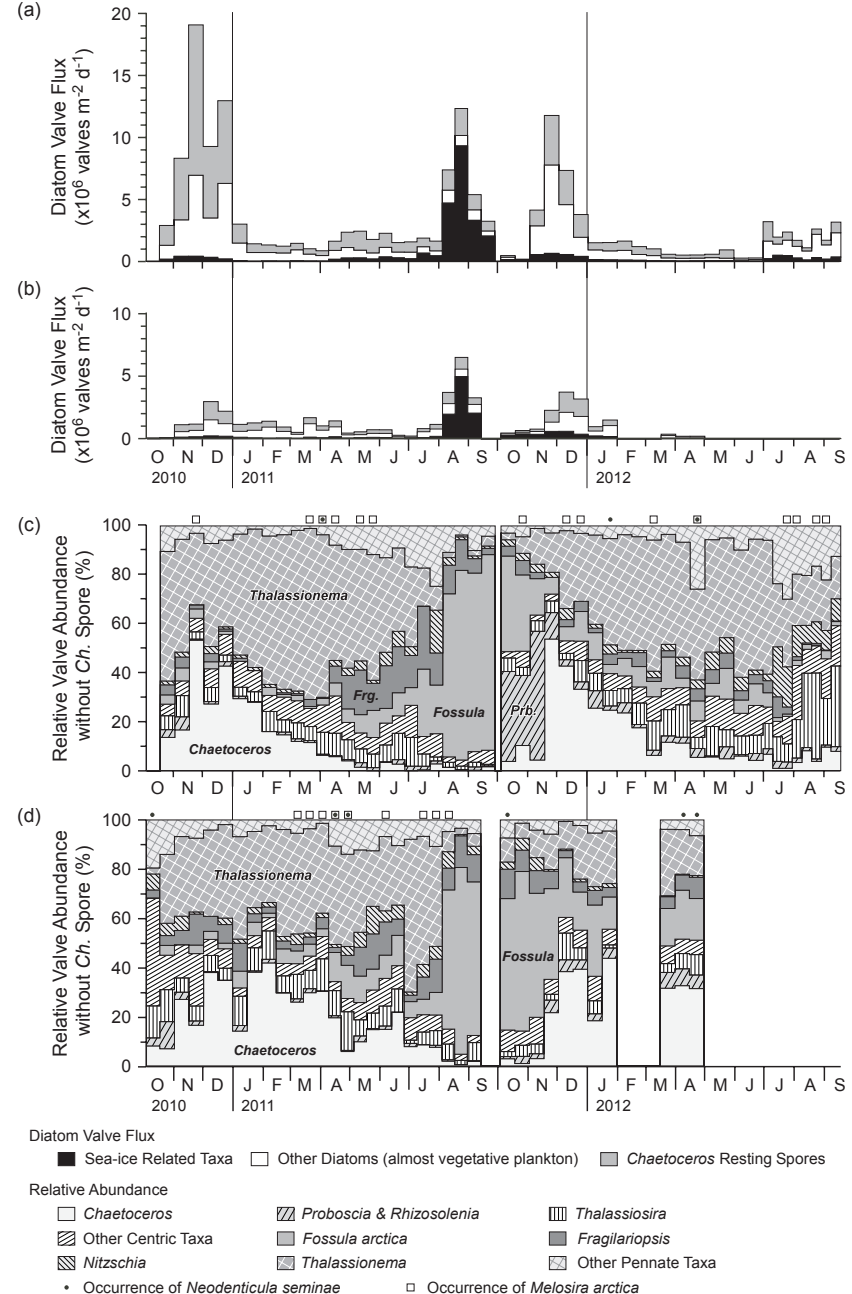

Figure 3. Total diatom flux and settling diatom assemblage at Station NAP from 4 October 2010 through 17 September 2012. (a) Sinking diatom flux at shallow trap, (b) sinking diatom flux at deep trap, (c) relative diatom valve abundance excluding Chaetoceros spores at shallow trap, and (d) relative diatom valve abundance excluding Chaetoceros spores at deep trap. Blanks in timeseries data indicate periods with no data because of limited sample volume or periods without sampling because of mooring turnaround. The plot data are listed in Table S1 in the Supplement.

skeletons, siliceous endoskeletons of dinoflagellate Actiniscus, chrysophyte cysts, ebridian flagellates, and palmales. The contribution of these siliceous flagellates to POC and biogenic opal fluxes appears minor compared to the contribution from diatoms and radiolarians. This result is different from a previous observation on the Mackenzie Shelf in the southwestern Beaufort Sea that showed a significant contribution by small flagellates to the POC flux (Forest et al., 2007).
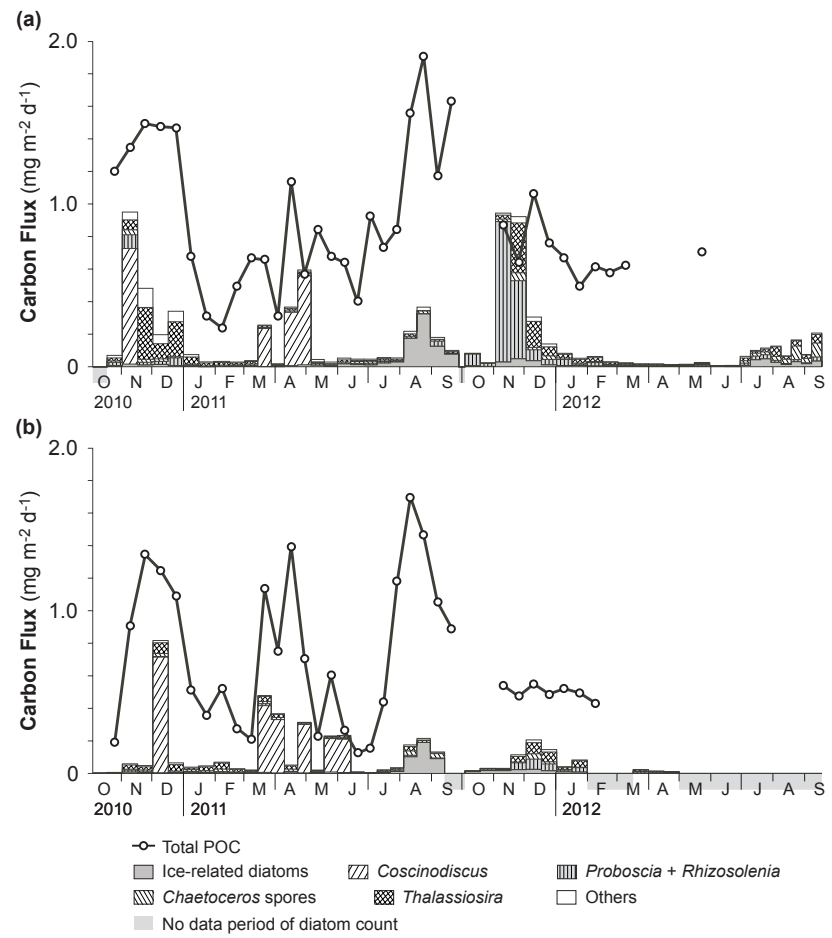

Figure 4. Time-series fluxes of total POC and diatom-derived carbon at Station NAP. (a) Shallow trap and (b) deep trap.

\subsection{Diatom POC flux}

In order to estimate the diatom contribution to POC flux, the diatom POC flux is required instead of the flux data for diatom valve abundance. Time-series fluctuations in the diatom POC flux and in the dominant taxa in diatom POC estimation differ from those of the diatom valve flux because of the temporary increases in the flux of larger centric diatoms (Figs. 3 and 4). The estimated diatom POC flux is based on observed valve numbers. It is therefore difficult to estimate the influence of selective decomposition of diatom valves and diatom carbon on the POC flux during the sinking process. In November-December most of the POC was attributed to Coscinodiscus, Rhizosolenia, and Chaetoceros (Fig. 4). A temporary increase in diatom POC flux was caused by the appearance of large Coscinodiscus in late March and from mid-April to early May 2011. The ice-related algae Fossula arctica was the primary species in diatom POC flux during August-September 2011. The high diatom POC flux from Rhizosolenia and Proboscia in November 2011 was evidenced by the abundant occurrence of the end parts of their needle-like valves rather than the abundant occurrence of intact cells. Thus, the diatom POC flux in November 2011 became overestimate and exceeded total POC flux. Proboscia was dominant in the eastern Chukchi Sea shelf waters in September-October 2010 (J. Onodera, unpublished data). The diatom POC flux in summer 2012 was composed mainly of Thalassiosira spp. Although vegetative Chaetoceros (sub- 
genus Hyalochaete) and Thalassionema were numerically abundant, their contribution to diatom POC was relatively minor because their cell volume is one to five orders smaller than Coscinodiscus, Rhizosolenia, Proboscia, and Thalassiosira.

\subsection{Diatom valve flux and species composition}

The total diatom flux captured in the shallow trap showed clear seasonality (Fig. 3a). A relatively high flux of diatom valves was observed in November-December 2010, AugustSeptember 2011, and November-December 2011 (Fig. 3a). The sinking diatom flux rapidly increased in August 2011, when the sea-ice retreated at Station NAP (Figs. 2b, 3a). The maximum of the total diatom flux at the shallow-trap depth in summer 2011 reached $11.3 \times 10^{6}$ valves $\mathrm{m}^{-2} \mathrm{~d}^{-1}$ in the period from 18 to 31 August. This maximum was approximately $28 \%$ of the diatom flux maximum at Station LOMO2 (150 m trap depth) in summer 1996 (Zernova et al., 2000). In 2012, a seasonal increase in total diatom flux started after June. However, the diatom flux and total mass flux in June-September 2012 were lower than those in summer 2011. The maximum fluxes reached $17.5 \times 10^{6}$ and $10.8 \times 10^{6}$ valves $\mathrm{m}^{-2} \mathrm{~d}^{-1}$ in early winter 2010 and 2011 , respectively. The high diatom flux season at the deep trap was similar to that at the shallow trap (Fig. 3a, b). However, the difference between the two traps was that the total diatom flux at the deep trap in summer 2011 was higher than those fluxes in early winter maxima of 2010 and 2011.

The diatoms found in all samples examined were categorized into 98 taxa (Table 1). Because diatom species usually observed in fresh or low-salinity water were very rare, the biogenic materials collected in this study were primarily of marine origin. In the shallow-trap samples, the genera Thalassionema and Chaetoceros (subgenus Hyalochaete) were the major components from late October 2010 to early July 2011 (Fig. 3c). Chaetoceros relatively increased in late November-December 2010. Thalassionema relatively increased in the low flux period and reached to $70 \%$ in March 2011. Then, Fragilariopsis (oceanica and cylindrus), which are sea-ice-related diatom species (Ren et al., 2014), gradually increased from April to August 2011. The sinking diatom assemblage in summer 2011 was mainly composed of Fossula arctica, one of the common sea-ice diatoms in the Arctic Ocean (Cremer, 1999; von Quillfeldt, 2003). The maximum relative abundance of $F$. arctica was $80 \%$ in 14-28 September 2011. After the period of F. arctica dominance, the relative abundance of Proboscia eumorpha increased in shallow-trap samples in October-November 2011 (Fig. 3c). The sinking diatom flora during the high-flux period of November-December 2011 was essentially the same as that in 2010, although the relative abundance of Chaetoceros resting spores was relatively minor compared to other diatoms (Fig. 3a, b). The relative increases in Fragilariopsis and Fossula were not observed in 2012. The relative abun- dance of sea-ice-related diatoms was less than $23 \%$ in summer 2012. Instead, relative abundance of planktic diatoms such as Thalassiosira spp. and Nitzschia spp. increased in settling diatom assemblage in summer 2012.

In comparison of shallow- and deep-trap diatom floras, the dominant species in settling diatom flora of two traps were the same in the periods of diatom flux maxima (Fig. 3d). However, time-series succession of major diatom species in deep-trap samples were unclear compared to that of shallow trap. The clear increase in the relative abundance of Proboscia observed at shallow trap in October-November 2011 was not observed at the deep trap.

Melosira arctica, which was commonly observed at Station LOMO2 (Zernova et al., 2000) and under summer sea ice in the northern Laptev Sea (Lalande et al., 2014), was rarely observed in our samples $(<2 \%$ numerical valve abundance). It has been reported that Neodenticula seminae is an endemic species in the subarctic North Pacific (Hasle, 1976; Yanagisawa and Akiba, 1990). This species has been expanding its distribution to the North Atlantic Ocean via the Arctic Ocean since 1999 (Reid et al., 2007). At Station NAP, $N$. seminae frustules and their fragments were sporadically observed in both shallow- and deep-trap samples (Fig. 3c, d). Some diatom valves were observed within aggregated clay minerals, which are considered an allochthonous component originating from the Chukchi Sea shelf.

\subsection{Sinking speed}

Using the time lag between the observed flux maxima at the shallow- and deep-trap depths, we estimated the average sinking speed of aggregated diatom particles between these depths at $37-75 \mathrm{~m} \mathrm{~d}^{-1}$ in November 2010 and $>85 \mathrm{~m} \mathrm{~d}^{-1}$ in August 2011. The faster sinking speed in August 2011 was primarily due to the abundant gelatinous material of zooplanktonic origin and the larger particle sizes resulting from chains of the diatoms Fossula arctica and Fragilariopsis spp.

\section{Discussion}

\subsection{Summer diatom flux and changes in upper water masses}

Because there are clearly differences in phytoplankton productivity and phytoplankton assemblages between the Chukchi Sea shelf and the Canada Basin, the settling diatom flux at Station NAP should reflect the times-series of hydrographic variations. The diatom flux and species composition observed in summer 2011 and 2012 likely reflected the dominance of different water masses - either shelf water or oligotrophic Beaufort Gyre water - in the upper water column. The high dominance of Fossula arctica at Station NAP in summer 2011 suggests the presence of sea ice transported from the highly productive Chukchi Sea shelf. This species is commonly observed in the spring assemblage of ice and 
Table 1. Diatom taxa found in sediment trap samples from Station NAP collected from 4 October 2010 to 18 September 2012 . The symbols “*” and "***" indicate sea-ice-related taxa and uncertain identification in this study, respectively.

\begin{tabular}{|c|c|}
\hline \multicolumn{2}{|l|}{ Taxa } \\
\hline Achnanthes brevipes Agardh 1824 & Neodenticula seminae (Simonsen \& Kanaya) Akiba \& Yanagisawa 1986 \\
\hline Achnanthes lanceolata (Brebisson) Grunow 1880** & Nitzschia arctica Cleve 1896* \\
\hline Actinocyclus curvatulus Janisch 1874 & Nitzschia frigida Grunow $1880^{*}$ \\
\hline Actinocyclus spp. & Nitzschia neofrigida Medlin 1990* \\
\hline Actinoptychus senarius (Ehrenberg) Ehrenberg 1843 & Nitzschia polaris (Grunow) Grunow 1884* \\
\hline Asteromphalus brookei Bailey 1856 & Nitzschia promare Medlin 1990* \\
\hline Asteromphalus hyalinus Karsten 1905 & Nitzschia seriata Cleve 1883 \\
\hline Aulacoseira spp. & Nitzschia spp. \\
\hline Bacillaria spp. & Odontella aurita (Lyngbye) Agardh 1832 \\
\hline Bacterosira fragilis (Gran) Gran 1900 & Paralia spp. \\
\hline Centric spp. & Pauliella taeniata (Grunow) Round \& Basson 1997 \\
\hline Chaetoceros (subgen. Chaetoceros) spp. & Pennate spp. \\
\hline Chaetoceros atlanticum Cleve 1873 & Pinnularia quadratarea (A.Schmidt) Cleve $1895^{*}$ \\
\hline Chaetoceros (subgen. Hyalochaete) spp. & Pinnularia quadratarea var. cuneata Østrup $1905^{*}$ \\
\hline Chaetoceros spp. resting spores & Pinnularia quadratarea var. dubia Heiden $1905^{*}$ \\
\hline Coscinodiscus oculus-iridis Ehrenberg 1839 & Pinnularia semiinflata (Østrup) Poulin \& Cardinal 1982 \\
\hline Coscinodiscus radiatus Enrenberg 1840 & Pinnularia spp. \\
\hline Craspedopleura kryophila (Cleve) Poulin 1993* & Pleurosigma stuxbergii Cleve \& Grunow $1880^{*}$ \\
\hline Cyclotella spp. & Pleurosigma spp. \\
\hline Cylindrotheca closterium (Ehrenberg) Lewin \& Reimann 1964 & Pseudo-nitzschia spp. \\
\hline Cymbella silesiaca Bleisch $1864^{* *}$ & Porosira glacialis (Grunow) Jørgensen 1905* \\
\hline Cymbella sinuata Gregory 1858 & Proboscia eumorpha Takahashi, Jordan \& Priddle 1994 \\
\hline Cymbella spp. & Pseudogomphonema arcticum (Grunow) Medlin 1986 \\
\hline Delphineis sp. cf. angustata (Pantocsek) Andrews 1981 & Pseudogomphonema septentrionale var. angustatum (Østrup) Medlin 1986* \\
\hline Delphineis surirella (Ehrenberg) Andrews 1981 & Pseudogomphonema spp. \\
\hline Diploneis litoralis var. clathrata (Østrup) Cleve $1896^{*}$ & Rhizosolenia borealis Sundström 1986 \\
\hline Diploneis sp. cf. bombus (Ehrenberg) Ehrenberg 1853 & Rhizosolenia hebetata Bailey 1856 \\
\hline Diploneis spp. & Rhizosolenia hebetata f. semispina (Hensen) Gran 1904** \\
\hline Entomoneis spp. & Rhizosolenia setigera Brightwell 1858 \\
\hline Eucampia groenlandica Cleve 1896 & Rhizosolenia spp. \\
\hline Fossula arctica Hasle, Syvertsen \& Quillfeldt $1996^{*}$ & Synedropsis hyperborea (Grunow) Hasle, Medlin \& Sybertsen 1994* \\
\hline Fragilariopsis cylindrus (Grunow) Krieger 1954* & Synedra spp. \\
\hline Fragilariopsis oceanica (Cleve) Hasle 1965* & Thalassiosira antarctica Comber 1896* \\
\hline Fragilariopsis spp. & Thalassiosira bioculata (Grunow) Ostenfeld 1903 \\
\hline Gyrosigma hudsonii Poulin \& Cardinal & Thalassiosira decipiens (Grunow) Jørgensen 1905** \\
\hline Gyrosigma macrum (W.Smith) Cleve 1894** & Thalassiosira eccentrica (Ehrenberg) Cleve $1904^{* *}$ \\
\hline Haslea crucigeroides (Hustedt) Simonsen 1974* & Thalassiosira hyalina (Grunow) Gran 1897 \\
\hline Licmophora sp. & Thalassiosira hyperborea (Grunow) Hasle 1989 \\
\hline Melosira arctica Dickie $1852^{*}$ & Thalassiosira leptopus (Grunow) Hasle \& Fryxell 1977 \\
\hline Melosira moniliformis (Müller) Agardh $1824^{* *}$ & Thalassiosira nordenskioeldii Cleve 1873 \\
\hline Navicula algida Grunow 1884* & Thalassiosira trifulta group \\
\hline Navicula directa (Smith) Ralfs 1861 & Thalassiosira spp. \\
\hline Navicula distans (Smith) Ralfs 1861 & Thalassionema nitzschioides (Grunow) Mereschkowsky 1902 \\
\hline Navicula forcipata var. densestriata Schmidt $1881^{* * *}$ & Thalassionema spp.** \\
\hline Navicula kariana var. detersa Grunow 1882* & Thalassiothrix sp. \\
\hline Navicula kryokonites Cleve $1883^{*}$ & Trachyneis aspera (Ehrenberg) Cleve 1894 \\
\hline Navicula obtusa Cleve $1883^{*}$ & \\
\hline Navicula superba Cleve 1883* & \\
\hline Navicula transitans Cleve $1883^{*}$ & \\
\hline Navicula transitans var. derasa (Grunow) Cleve 1883* & \\
\hline Navicula valida Cleve \& Grunow $1880^{*}$ & \\
\hline Navicula spp. & \\
\hline
\end{tabular}



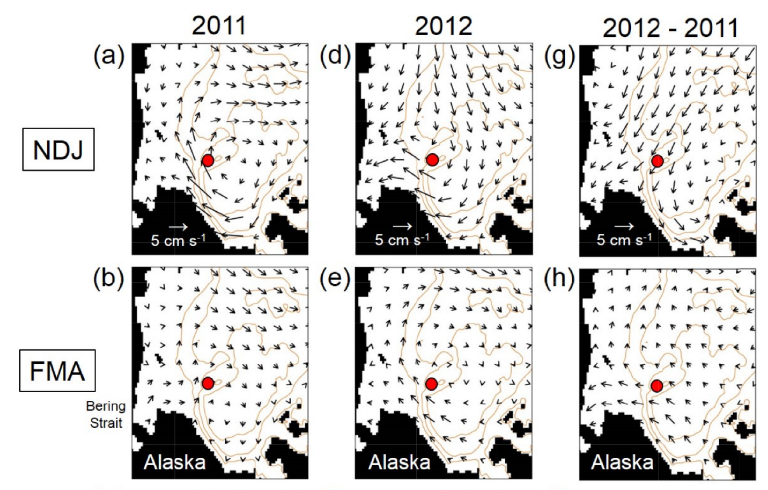

(f)
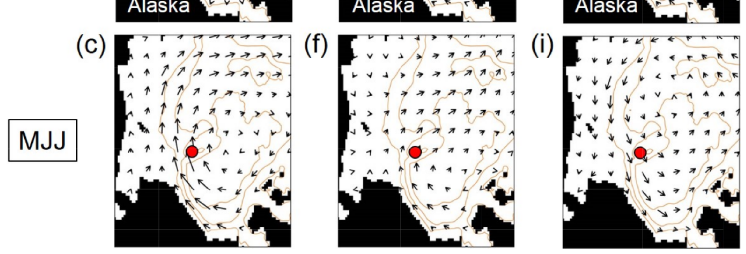

Figure 5. Sea ice motion vectors in the western Arctic Ocean derived from the Polar Pathfinder data set in (a-c) 2011 and (ef) 2012. Panels (g-i) show their difference (2012 minus 2011). Seasonal averages for $(\mathbf{a}, \mathbf{d}, \mathbf{g})$ November to January, $(\mathbf{b}, \mathbf{e}, \mathbf{h})$ February to April, and (c, f, i) May to July were calculated from monthly mean data. Each vector in the EASE grid was interpolated to the COCO model grid for comparison, and the obtained vectors are shown every eight grids (approximately $200 \mathrm{~km}$ ). Unit vector corresponds to $5 \mathrm{~cm} \mathrm{~s}^{-1}$. The location of Station NAP is presented by the red circular symbol. Thin contours indicate isobaths of 100, 1000, and $3000 \mathrm{~m}$.

water in the Chukchi Sea (von Quillfeldt et al., 2003). According to data for the biogeographic distribution of diatoms in the Laptev Sea, F. arctica is mainly observed in the seaice assemblage around shelf zones rather than on the basin side (Cremer, 1999). The relatively high flux of lithogenic material in 2011 also suggests that many of the particles trapped in this study originated primarily from the Chukchi Sea shelf. During October 2010, there was a high cell density of Proboscia eumorpha over the eastern Chukchi Sea shelf, whereas there were low cell densities of Proboscia species in water samples from the southwestern Canada Basin and the Northwind Abyssal Plain (J. Onodera, unpublished data). The relative increase in $P$. eumorpha after the period of $F$. arctica dominance in 2011 suggests the influence of Chukchi Shelf waters at Station NAP.

The transport of coastal water toward Station NAP in summer 2011 was also inferred from the presence of the $\mathrm{Pa}$ cific copepod Neocalanus cristatus in sediment traps (Matsuno et al., 2014). Also present was abundant gelatinous zooplankton material, such as the "houses" of appendicularians (Oikopleuridae) (S. Chiba, personal communication, 2014), in August-September 2011. In contrast to 2011, the limited influence of shelf-origin sea ice and shelf waters around Station NAP in 2012 is evidenced by the absence of biogenic and lithogenic particles in trap samples and the rare occur-
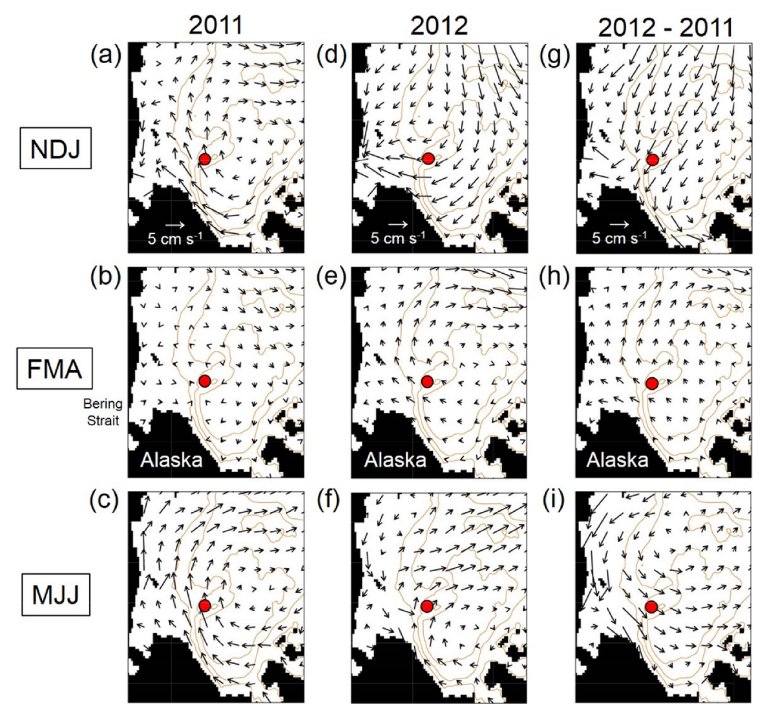

Figure 6. Same as Fig. 5 but for the COCO model result.

rence of $F$. arctica and other coastal biogenic particles in January-September 2012.

To examine the mechanisms behind the suppressed biogenic fluxes in summer 2012, we addressed the relationship between horizontal advection and settling particle fluxes using satellite-based sea-ice motion data and the pan-Arctic ice-ocean model. The sea-ice and water-mass properties at Station NAP should be considered to be occasionally influenced by interannual variability in the Beaufort Gyre circulation. First, we checked the Polar Pathfinder sea-ice motion vectors and determined the seasonal averages in the western Arctic Ocean (Fig. 5). During the winter, from November 2010 to January 2011, an anticyclonic sea-ice circulation (normally referred to as the "Beaufort Gyre") appeared over the Canada Basin and Chukchi Borderland. This pattern subsided once in early spring and then returned for the summer season from May to July 2011. Thus, in 2011, the source region for sea ice around Station NAP would have been the southern Beaufort Sea. In contrast, there was prevailing southward sea-ice motion from winter to spring 2012. The anticyclonic circulation appeared again in the region the following early summer, but its strength was clearly weaker than in 2011. This difference between the two years also suggests that shelf-origin sea ice had less effect on settling particle fluxes around Station NAP in 2012.

We next analyzed the results from our interannual experiment using the $25 \mathrm{~km}$ grid COCO model. The spatial pattern of simulated sea-ice motion produced by this model was nearly the same as the satellite-based one (Fig. 6). We then compared the simulated sea-surface height in the western Arctic Ocean using the summertime averages in 2011 and 2012 (Fig. 7). In general, the spatial pattern of sea-surface height reflects the intensity and location of the oceanic Beaufort Gyre. The COCO model demonstrated that the sea- 

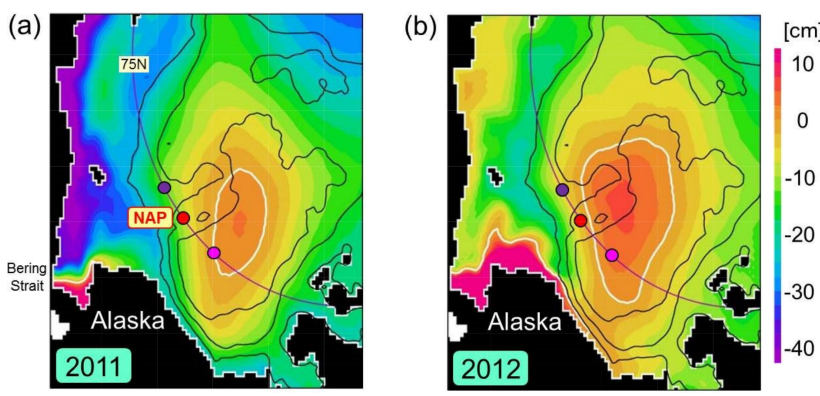

Figure 7. Sea surface height $(\mathrm{cm})$ in the western Arctic Ocean obtained from the COCO model. The summertime averages over June, July, and August are shown for (a) 2011 and (b) 2012. Black contours trace isobaths of 100,1000 , and $3000 \mathrm{~m}$. The white contours indicate a sea-surface height of zero. The purple line corresponds to $75^{\circ} \mathrm{N}$, used for modeled current direction in Fig. 8. Red dots show the location of Station NAP. Purple dots represent the east and west limits of the horizontal section in Fig. 8.

surface height was greater over the entire western Arctic Basin, and the maximum height was located more to the western side of the basin in summer 2012 than in summer 2011. This difference between the two years indicates that the Beaufort Gyre expanded toward the Chukchi Borderland in 2012.

The 5-year time series of simulated ocean current direction in the surface $100 \mathrm{~m}$ layer shows that a northwestward current frequently prevailed east of Station NAP (Fig. 8). This situation favors the spread of shelf-origin water, with a high abundance of coastal diatom taxa and lithogenic materials, toward the Chukchi Borderland. The model results also show that the current direction switched southwestward in December 2011. Because the central Canada Basin is known as an oligotrophic region (Nishino et al., 2011a), the transport of nutrient-poor basin water toward Station NAP following this change in prevailing current direction is a possible factor explaining the lower diatom flux in summer 2012. These model results suggest that variations in the Beaufort Gyre significantly influenced nutrient availability and the consequent biogenic fluxes at Station NAP.

\subsection{Lateral advection of coastal diatoms in early winter}

Based on biogeographic characteristics, much of the Chaetoceros resting spores and other coastal diatoms in the studied samples can be regarded as allochthonous materials transported from shelf to basin. Compared to previous studies of particulate carbon fluxes in the Arctic Ocean (summarized in Wassmann et al., 2004), the early winter maximum of POC flux in our study is unusual under conditions of seaice cover and polar night. No diatom flux maximum was observed in any early winter during the previous diatom flux study at Station LOMO2 from September 1995 to August 1996 (Zernova et al., 2000). Because polar diatoms show tolerance to low light intensity (Lee et al., 2008), the autumn

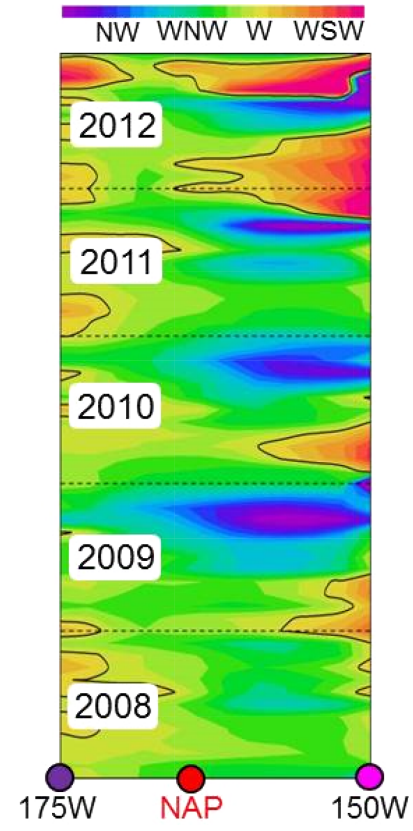

Figure 8. Modeled ocean current direction averaged from the surface to $100 \mathrm{~m}$ depth across an east-west section along $75^{\circ} \mathrm{N}$ (see purple line in Fig. 7). The vertical axis represents an interannual time series from 2008 to 2012. Blue (red) indicates a northwestward (southwestward) ocean current.

diatom production probably continued under sea-ice cover and decreasing solar radiation at Station NAP after late October (Fig. 2a, b). However, the high diatom production and subsequent flux of settling diatoms and other biogenic particles, which were comparable to those in the summer, cannot be explained on the basis of the general seasonality of primary production and sinking particle flux in the seasonal sea-ice zone of the Arctic Ocean (Wassmann et al., 2004; Wassmann and Reigstad, 2011). In this study, we also observed the annual maximum of lithogenic particle flux during the period of high sinking diatom flux in NovemberDecember (Figs. 2 and 3; Watanabe et al., 2014). In the early winter of each year, the origin of diatom particles comprising the diatom flux maximum around Station NAP should be treated as a complex of transported shelf-origin materials and autochthonous diatoms. The dominance of Chaetoceros (subgenus Hyalochaete) spp. and their resting spores, and the abundant silt-clay minerals in the studied samples, suggests the substantial influence of Chukchi Sea shelf waters.

The increased supply of coastal diatoms and lithogenic materials in the basin in early winter can be explained by several possible mechanisms. For example, the resuspension of shelf bottom materials into the upper water column would result in the continuous dominance of lithogenic materials, including valves of coastal diatoms, in the studied particles at Station NAP. In addition, suspended neritic diatoms are incorporated into sea ice and driven offshore (Różańska et 
al., 2008). However, sea-ice drift and the usual resuspension of shelf materials cannot fully explain the early winter flux maxima of diatoms and lithogenic particles at Station NAP. The high-resolution pan-Arctic Ocean model COCO demonstrated that a drifting anticyclonic cold eddy generated north of Point Barrow in June 2010 passed Station NAP at the 100 to $200 \mathrm{~m}$ water depth during late October-early December 2010 (Watanabe et al., 2014). The simulated passage of the cold eddy was consistent with the observed event-like cooling and deepening of the moored trap depth that we recorded in late October-December 2010 (Fig. 2c, d). In addition, this eddy continued to pull cold water from the outer shelf during the early part of its passage from off Point Barrow toward Station NAP. Therefore, the movement of the cold eddy could account for the appearance of the high proportion of shelf bottom water at Station NAP in late October-early December (Fig. S2.2 in Watanabe et al., 2014).

Based on the observed characteristics of diatom floral fluxes and the physical oceanographic simulation, we suggest that the early winter maximum of diatom flux observed in this study was caused primarily by a drifting cold eddy that developed along the shelf break off Point Barrow (Watanabe et al., 2014). The smaller maximum in diatom flux at the deep-trap depth in early winter probably reflects the horizontal diffusion of settling particles in deeper layers under the eddy (Siegel et al., 1990) in addition to biogenic particle decomposition. Whereas eddy-induced lateral transport of coastal materials has been reported in the Canada Basin (O'Brien et al., 2011, 2013; Nishino et al., 2011b), the eddy in this study, composed of Pacific-origin waters with lower density, did not flow down the shelf slope. Because the shallow sediment trap was moored at about $260 \mathrm{~m}$ during the second deployment, the temperature and pressure sensors attached to the sediment trap did not detect the direct influence of the cold eddy. However, a similar event involving eddyinduced transport of shelf materials to the basin in early winter 2011 is evident in the high diatom flux, the characteristic diatom assemblage, and the high abundance of lithogenic clay particles.

\subsection{Role of diatoms in the biological pump}

Because biogenic opal has a ballast effect on the export of particulate organic matter to deep basins (Honjo et al., 2008; Honda and Watanabe, 2010), the biological pump is usually effective in diatom-rich oceans such as the Aleutian Basin in the Bering Sea (Takahashi et al., 2002), the subarctic North Pacific (Honda et al., 2002; Takahashi et al., 2002; Honda and Watanabe, 2010), and the Southern Ocean (Honjo et al., 2008). However, most settling autochthonous POC in the central Canada Basin is remineralized within subsurface layers (Honjo et al., 2010). Fresh POC is not supplied to deeper layers, even though there is primary production of 2-4 mol C m ${ }^{-2} \mathrm{yr}^{-1}$ (Honjo et al., 2010). The primary producers in the cryopelagic Canada Basin are mainly green al- gae and other picoplankton (e.g., Coupel et al., 2012). The ineffective biological pump in the Canada Basin can be explained by the limited amounts of diatoms supplying biogenic ballast and fecal pellets (Honjo et al., 2010). The relatively abundant POC fluxes at Station NAP, as compared to those at the sediment trap of Station CD04-3067 m (trap depth: $3067 \mathrm{~m}$ ) in the central Canada Basin (Honjo et al., 2010), are due to the higher lateral carbon transport from the Chukchi Sea shelf and autochthonous production of phytoplankton and zooplankton around Station NAP (Watanabe et al., 2014).

The diatoms collected in our samples sometimes retained frustules in chain form. Furthermore, frustules with residual protoplasm were also observed in summer samples. Their occurrence suggests that the carbon supplied to the deep sea in the Northwind Abyssal Plain includes not only old carbon transported from the shelf or sea-floor ridge, but also fresh carbon produced around the study area. When the influence of shelf-origin water is obvious at Station NAP, as in 2011, the biological pump at Station NAP will be relatively active owing to abundant supplies of biogenic and lithogenic particles. In contrast, when oligotrophic water from the central Canada Basin is supplied to Station NAP, as observed in early 2012, the sinking particle flux at Station NAP will be limited. In this situation, the efficiency of the biological pump might be reduced to a level comparable to that in the central Canada Basin. Therefore, on the Chukchi shelf side of the outer Beaufort Gyre, primary productivity and the biological pump are influenced by the spatial distribution of upper water masses (Nishino et al., 2011a). When oligotrophic seasurface waters reduce the summer particle flux, as was evident in summer 2012, the eddy effect on lateral advection of shelf materials to the basin (Nishino et al., 2011b; O'Brien et al., 2011, 2013; Watanabe et al., 2014) becomes important to the seasonality of organic matter flux and the composition of the sinking microplankton flora in the study area (Watanabe et al., 2014).

\section{The Supplement related to this article is available online at doi:10.5194/bg-12-1373-2015-supplement.}

Author contributions. N. Harada planned the research project. J. Onodera carried out the diatom analysis and offshore work of sediment-trap mooring experiments. E. Watanabe implemented the physical oceanographic model. M. C. Honda analyzed the biogenic opal in sediment trap samples. J. Onodera and E. Watanabe prepared the manuscript with contributions from all co-authors.

Acknowledgements. We gratefully thank the captains, crews, chief scientists, and marine technicians of R/V Mirai and I/B CCGS Sir Wilfrid Laurier for mooring operations; Takashi Kikuchi for 
cruise logistics; and Yuichiro Tanaka for supplying sediment trap equipment. This work was funded through a Grant-in-Aid for Scientific Research (S) of the Japan Society for the Promotion of Science (JSPS) (JFY2010-2014, no. 22221003, "Catastrophic reduction of sea ice in the Arctic Ocean: its impact on the marine ecosystems in the polar region") to N. Harada, and through a JSPS Research Fellowship for Young Scientists to J. Onodera (no. 22-5808). Modeling experiments were executed by E. Watanabe using the Japan Agency for Marine-Earth Science and Technology (JAMSTEC) Earth Simulator version 2.

Edited by: G. Herndl

\section{References}

Ardyna, M., Gosselin, M., Michel, C., Poulin, M., and Tremblay, J.-É.: Environmental forcing of phytoplankton community structure and function in the Canadian High Arctic: contrasting oligotraphic and eutrophic regions, Mar. Ecol. Prog. Ser., 442, 37-57, 2011

Ardyna, M., Babin, M., Gosselin, M., Devred, E., Rainville, L., and Tremblay, J.-É.: Recent Arctic Ocean sea ice loss triggers novel fall phytoplankton blooms, Geophys. Res. Lett., 41, 6207-6212, 2014.

Arrigo, K. R., Perovich, D.K., Pickart, R. S., Brown, Z. W., van Dijken, G. L., Lowry, K. E., Mills, M. M., Palmer, M. A., Balch, W. M., Bahr, F., Bates, N. R., Benitez-Nelson, C., Bowler, B., Brownlee, E., Ehn, J. K., Frey, K. E., Garley, R., laney, S. R., Lubelczyk, L, Mathis, J., Matsuoka, A., Mitchell, B. G., Mooore, W. K., Ortega-Retuerta, E., Ppal, S., Polashenski, C. M., Reynolds, R.A., Schieber, B., Sosik, H. M., Stephens, M., and Swift, J. H.: Massive phytoplankton blooms under Arctic sea ice, Science, 336, 1408, doi:10.1126/science.1215065, 2012.

Bauerfeind, E., Nöthig, E-M., Beszczynska, A., Fahl, K., Kaleschke, L., Kreker, K., Klages, M, Soltwedel, T., Lorenzen, C., and Wegner, J.: Particle sedimentation patterns in the eastern Fram Strait during 2000-2005: Results from the Arctic long-term observatory HAUSGARTEN, Deep-Sea Res. I, 56, 1471-1487, 2009.

Bitz, C. M. and Lipscomb, W. H.: An energy-conserving thermodynamic model of sea ice, J. Geophys. Res., 104, 15669-15677, 1999.

Coachman, L. K. and Barnes, C. A.: The contribution of Bering Sea water to the Arctic Ocean, Arctic, 14, 147-161, 1961.

Coupel, P., Jin, H. Y., Joo, M., Horner, R., Bouvet, H. A., Sicre, M.-A., Gascard, J.-C., Chen, J. F., Garçon, V., and RuizPino, D.: Phytoplankton distribution in unusually low sea ice cover over the Pacific Arctic, Biogeosciences, 9, 4835-4850, doi:10.5194/bg-9-4835-2012, 2012.

Cremer, H.: Distribution patterns of diatom surface sediment assemblages in the Laptev Sea (Arctic Ocean), Mar. Micropaleontol., 38, 39-67, 1999.

Danielson, S., Curchitser, E., Hedstrom, K., Weingartner, T., and Stabeno, P.: On ocean and sea ice modes of variability in the Bering Sea, J. Geophys. Res., 116, C12036, doi:10.1029/2011JC007389, 2011.

Fahl, K. and Nöthig, E. -M.: Lithogenic and biogenic particle fluxes on the Lomonosov Ridge (central Arctic Ocean) and their rele- vance for sediment accumulation: Vertical vs. lateral transport, Deep-Sea Res. Pt. I, 54, 1256-1272, 2007.

Forest, A., Sampei, M., Hattori, H., Makabe, R., Sasaki, H., Fukuchi, M., Wassmann, P., and Fortier, L.: Particulate organic carbon fluxes on the slope of the Mackenzie Shelf (Beaufort Sea): Physical and biological forcing of shelf-basin exchanges, J. Mar. Sys., 68, 39-54, 2007.

Forest, A., Galindo, V., Darnis, G., Pineault, S., Lalande, C., Tremblay, J.-E., and Fortier, L.: Carbon biomass, elemental ratios $(\mathrm{C}: \mathrm{N})$ and stable isotopic composition $\left(\delta^{13} \mathrm{C}, \delta^{15} \mathrm{~N}\right)$ of dominant calanoid copepods during the winter-to-summer transition in the Amundsen gulf (Arctic Ocean), J. Plankton Res., 33, 161-178, 2011.

Fowler, C., Emery, W., and Tschudi, M.: Polar Pathfinder Daily $25 \mathrm{~km}$ EASE-Grid Sea Ice Motion Vectors, Version 2, Boulder, Colorado USA: National Snow and Ice Data Center, 2013.

Fukuchi, M., Sasaki, H., Hattori, H., Matuda, O, Tanimura, A., Handa, N., and McRoy, C. P.: Temporal variability of particulate flux in the northern Bering Sea, Cont. Shelf Res., 13, 693-704, 1993.

Gaye, B., Fahl, K., Kodina, L. A., Lahajnar, N., Nagel, B., Unger, D., and Gebhardt, A. C.: Particulate matter fluxes in the southern and central Kara Sea compared to sediments: Bulk fluxes, amino acids, stable carbon and nitrogen isotopes, sterols and fatty acids, Cont. Shelf Res., 27, 2570-2594, 2007.

Grebmeier, J. M., Moore, S. E., Overland, J. E., Frey, K. E., and Gradinger, R.: Biological response to recent Pacific Arctic sea ice retreats, Eos, 91, 161-162, 2010.

Hargrave, B. T., von Bodungen, B., Conover, R. J., Fraser, A. J., Phyllips, G., and Vass, W. P.: Seasonal changes in sedimentation of particulate matter and lipid content of zooplankton collected by sediment trap in the Arctic Ocean off Axel Heiberg Island, Polar Biol., 9, 467-475, 1989.

Hasle, G. R.: The biogeography of some marine planktonic diatoms, Deep-Sea Res., 23, 319-338, 1976.

Hasumi, H.: CCSR Ocean Component Model (COCO) version 4.0. Center for Clim. Sys. Res. Rep., Univ. of Tokyo, 25, 1-103, 2006.

Honda, M. C. and Watanabe, S.: Importance of biogenic opal as ballast of particulate organic carbon (POC) transport and existence of mineral ballast-associated and residual POC in the Western Pacific Subarctic Gyre, Geophys. Res. Lett., 37, L02605, doi:10.1029/2009GL041521, 2010.

Honda, M. C., Imai, K., Nojiri, Y., Hoshi, F., Sugawara, T., and Kusakabe, M.: The biological pump in the northwestern North Pacific based on fluxes and major components of particulate matter obtained by sediment-trap experiments (1997-2000), DeepSea Res. Pt. II, 49, 5595-5625, 2002.

Honjo, S., Manganini, S. J., Krishfield, R. A., and Francois, R.: Particulate organic carbon fluxes to the ocean interior and factors controlling the biological pump: A synthesis of global sediment trap programs since 1983, Prog. Oceanogr., 76, 217-285, 2008.

Honjo, S., Krishfield, R. A., Eglinton, T. I., Manganini, S. J., Kemp, J. N., Doherty, K., Hwang, J., McKee, T. K., and Takizawa, T. Biological pump processes in the cryopelagic and hemipelagic Arctic Ocean: Canada Basin and Chukchi Rise. Prog. Oceanogr., 85, 137-170, 2010.

Hunke, E. C. and Dukowicz, J. K.: An elastic-viscous-plastic model for sea ice dynamics, J. Phys. Oceanogr., 27, 1849-1867, 1997. 
Ikenoue, T., Bjørklund, K. R., Kruglikova, S. B., Onodera, J., Kimoto, K., and Harada, N.: Flux variations and vertical distributions of microzooplankton (Radiolaria) in the western Arctic Ocean: environmental indices in a warming Arctic, Biogeosciences Discuss., 11, 16645-16701, doi:10.5194/bgd-1116645-2014, 2014

Joo, H. M., Lee, S. H., Jung, S. W., Dahms, H.-U., and Lee, J. H.: Latitudinal variation of phytoplankton communities in the western Arctic Ocean, Deep-Sea Res. Pt. II, 81-84, 3-17, 2012.

Kalnay, E., Kanamitsu, M., Kistler, R., Collins, W., Deaven, D., Gandin, L., Iredell, M., Saha, S., White, G., Woollen, J., Zhu, Y., Chelliah, M., Ebisuzaki, W., Higgins, W., Janowiak, J., Mo, K. C., Ropelewski, C., Wang, J., Leetmaa, A., Reynolds, R., Jenne, R., and D. Joseph: The NCEP/NCAR 40-year reanalysis project, Bull. Amer. Meteor. Soc., 77, 437-471, 1996.

Lalande, C., Bélanger, S., and Fortier, L.: Impact of a decreasing sea ice cover on the vertical export of particulate organic carbon in the northern Laptev Sea, Siberian Arctic Ocean, Geohys. Res. Lett., 36, L21604, doi:10.1029/2009GL040570, 2009.

Lalande, C., Nöthig, E.-M., Somavilla, R., Bauerfeind, E., Shevchenko, V., and Kolodkov, Y.: Variability in under-ice export fluxes of biogenic matter in the Arctic Ocean, Global Biogeochem. Cy., 28, 571-583, doi:10.1002/2013GB004735, 2014.

Laney, S. R. and Sosik, H. M.: Phytoplankton assemblage structure in and around a massive under-ice bloom in the Chukchi Sea, Deep-Sea Res. Pt. II, 105, 30-41, 2014.

Lee, S. H., Whitledge, T. E., and Kang, S. H.: Carbon uptake rates of sea ice algae and phytoplankton under different light intensities in a landfast sea ice zone, Barrow, Alaska, Arctic, 61, 281-291, 2008.

Leonard, B. P., MacVean, M. K., and Lock, A. P.: The flux-integral method for multi-dimensional convection and diffusion, NASA Tech. Memo., 106679, ICOMP-94-13, 1994.

Matsuno, K., Yamaguchi, A., Fujiwara, A., Onodera, J., Watanabe, E., Imai, I., Chiba, S., Harada, N., and Kikuchi, T.: Seasonal changes in mesozooplankton swimmers collected by sediment trap moored at a single station on the Northwind Abyssal Plain in the western Arctic Ocean, J. Plankton Res., 36, 490-502, 2014.

McLaughlin, F., Carmack, E., Proshutinsky, A., Krishfield, R. A., Guay, C., Yamamoto-Kawai, M., Jackson, J. M., and Williams, B.: The rapid response of the Canada Basin to climate forcing: From bellwether to alarm bells, Oceanography, 24, 146-159, 2011.

McLaughlin, F. A. and Carmack, E. C.: Deepening of the nutricline and chlorophyll maximum in the Canada Basin interior, 2003-2009, Geophys. Res. Lett., 37, L24602, doi:10.1029/2010GL045459, 2010.

McPhee, M. G.: Intensification of geostrophic currents in the Canada Basin, Arctic Ocean, J. Climate, 26, 3130-3138, 2013.

Menden-Deuer, S. and Lessard, E. J.: Carbon to volume relationships for dinoflagellates, diatoms, and other protist plankton, Limnol. Oceanogr., 45, 569-579, 2000.

Nishino, S., Kikuchi, T., Yamamoto-Kawai, M., Kawaguchi, Y., Hirawake, T., and Itoh, M.: Enhancement/reduction of biological pump depends on ocean circulation in the sea-ice reduction regions of the Arctic Ocean, J. Oceanogr., 67, 305-314, 2011 a.

Nishino, S., Itoh, M., Kawaguchi, Y., Kikuchi, T., and Aoyama, M.: Impact of an unusually large warm-core eddy on distributions of nutrients and phytoplankton in the southwestern Canada
Basin during late summer/early fall 2010, Geophys. Res. Lett., 38, L16602, doi:10.1029/2011GL047885, 2011b.

Nishino, S., Itoh, M., Williams, W. J., and Semiletov, I.: Shoaling of the nutricline with an increase in near-freezing temperature water in the Makarov Basin, J. Geophys. Res.-Oceans, 118, 635-649, doi:10.1029/2012JC008234, 2013.

O’Brien, M. C., Melling, H., Pedersen, T. F., and Macdonald, R. W.: The role of eddies and energetic ocean phenomena in the transport of sediment from shelf to basin in the Arctic, J. Geophys. Res., 116, C08001, doi:10.1029/2010JC006890, 2011.

O'Brien, M.C., Melling, H., Pedersen, T. F., and Macdonald, R. W.: The role of eddies on particle flux in the Canada Basin of the Arctic Ocean, Deep-Sea Res. Pt. I, 71, 1-20, 2013.

Onodera, J., Takahashi, K., and Honda, M. C.: Pelagic and coastal diatom fluxes and the environmental changes in the northwestern North Pacific during December 1997-May 2000, Deep-Sea Res. II, 52, 2218-2239, 2005.

Reid, P. C., Johns, D. G., Edwards, M., Starr, M., Poulin, M., and Snoeijs, P.: A biological consequence of reducing Arctic ice cover: arrival of the Pacific diatom Neodencitula seminae in the North Atlantic for the first time in 800000 years, Gl. Ch. Biol., 13, 1910-1921, 2007.

Ren, J., Gersonde, R., Esper, O., and Sancetta, C.: Diatom distributions in northern North Pacific surface sediments and their relationship to modern environmental variables, Palaeogeogr. Palaeoclimatol. Palaeoecol., 402, 81-103, 2014.

Reynolds, R. W., Rayner, N. A., Smith, T. M., Stokes, D. C., and Wang, W.: An improved in situ and satellite SST Analysis for climate, J. Climate, 15, 1609-1625, 2002.

Różańska, M., Poulin, M., and Gosselin, M.: Protist entrapment in newly formed sea ice in the Coastal Arctic Ocean, J. Mar. Sys. 74, 887-901, 2008.

Saha, S., Moorthi, S., Pan, H-L., Wu, X., Wang, J., Nadiga, S., Tripp, P., Kistler, R., Woollen, J., Behringer, D., Liu, H., Stokes, D., Grumbine, R., Gayno, G., Wang, J., Hou, Y.-T., Chuang, H., Juang, H.-M. H., Sela, J., Iredell, M., Treadon, R., Kleist, D., Delst, P. V., Keyser, D., Derber, J., Ek, M., Meng, J., Wei, H., Yang, R., Lord, S., van den Dool, H., Kumar, A., Wang, W., Long, C., Chelliah, M, Xue, Y., Huang, B., Schemm, J-K., Ebisuzaki, W., Lin, R., Xie, P., Chen, M., Zhou, S., Higgins, W., Zou, C-Z., Liu, Q., Chen, Y., Han, Y., Cucurull, L., Reynolds, R. W., Rutledge, G., and Goldberg, M.: The NCEP Climate Forecast System Reanalysis, Bull. Amer. Meteor. Soc., 91, 1015-1057, 2010.

Sampei, M., Sasaki, H., Makabe, R., Forest, A., Hattori, H., Tremblay, J.-E., Gratton, Y., Fukuchi, M., and Fortier, L.: Production and retention of biogenic matter in the southeast Beaufort Sea during 2003-2004: insightz from annual vertical particle fluxes of organic carbon and biogenic silica, Polar Biol., 34, 501-511, 2011.

Siegel, D. A., Granata, T. C., Michaels, A. F., and Dickey, T. D.: Mesoscale eddy diffusion, particle sinking, and the interpretation of sediment trap data, J. Geophys. Res., 95, 5305-5311, 1990.

Steele, M., Morley, R., and Ermold, W.: PHC: A global ocean hydrography with a high-quality Arctic Ocean, J. Climate, 14, 2079-2087, 2001.

Steele, M., Morison, J., Ermold, W., Rigor, I., Ortmeyer, M., and Shimada, K.: Circulation of summer Pacific halocline 
water in the Arctic Ocean, J. Geophys. Res., 109, C02027, doi:10.1029/2003JC002009, 2004.

Stroeve, J. C., Serreze, M. C., Holland, M. M., Kay, J. E., Malanik, J., and Barrett, A. P.: The Arctic's rapidly shrinking sea ice cover: a research synthesis, Clim. Ch., 110, 1005-1027, doi:10.1007/s10584-011-0101-1, 2012.

Sukhanova, I. N., Flint, M. V., Pautova, L. A., Stockwell, D. A., Grebmeier, J. M., and Sergeeva, V. M.: Phytoplankton of the western Arctic in the spring and summer of 2002: Structure and seasonal changes, Deep-Sea Res. Pt. II, 56, 1223-1236, 2009.

Takahashi, K., Fujitani, N., and Yanada, M.: Long term monitoring of particle fluxes in the Bering Sea and the central subarctic Pacific Ocean, 1990-2000, Prog. Oceanogr., 55, 95-112, 2002.

von Quillfeldt, C. H. , Ambrose Jr., W. G., and Clough, L. M.: High number of diatom species in first-year ice from the Chukchi Sea, Polar Biol., 26, 806-818, 2003.

Wassmann, P. and Reigstad, M.: Future Arctic Ocean seasonal ice zones and implications for pelagic-benthic coupling, Oceanogr., 24, 220-231, 2011.

Wassmann, P., Bauerfeind, E., Fortier, M., Fukuchi, M., Hargrave, B., Moran, B., Noji, T., Nöthig, E.-M., Olli, K., Peinert, R., Sasaki, H., and Shevchenko, V.: Particulate organic carbon flux to the Arctic Ocean sea floor, in: The organic carbon cycle in the Arctic Ocean, edited by: Stein, R. and Macdonald, R. W., Berlin, Springer, 101-138, 2004.
Wassmann, P., Duarte, C. M., Agust, S., and Sejr, M. K.: Footprints of climate change in the Arctic marine ecosystem, Glob. Change Biol., 17, 1235-1249, doi:10.1111/j.1365-2486.2010.02311.x, 2011.

Watanabe, E.: Linkages among halocline variability, shelf-basin interaction, and wind regimes in the Beaufort Sea demonstrated in pan-Arctic Ocean modeling framework, Ocean Model., 71, 4353, doi:10.1016/j.ocemod.2012.12.010, 2013.

Watanabe, E. and Hasumi, H.: Pacific water transport in the western Arctic Ocean simulated by an eddy-resolving coupled sea iceocean model, J. Phys. Oceanogr., 39, 2194-2211, 2009.

Watanabe, E. and Ogi, M.: How does Arctic summer wind modulate sea ice-ocean heat balance in the Canada Basin?, Geophys. Res. Lett., 40, 1569-1574, doi:10.1002/grl.50363, 2013.

Watanabe, E., Onodera, J., Harada, N., Honda, M. C., Kimoto, K., Kikuchi, T., Nishino, S., Mtsuno, K., Yamaguchi, A., Ishida, A., and Kishi, M. J.: An enhanced role of eddies in the Arctic marine biological pump, Nat. Commun., 5, 3950, doi:10.1038/ncomms4950, 2014.

Yanagisawa, Y. and Akiba, F.: Taxonomy and phylogeny of the three marine diatom genera, Crucidenticula, Denticulopsis and Neodenticula, Bull. Geol. Surv. Japan, 41, 197-301, 1990.

Zernova, V. V., Nöthig, E.-M., and Shevchenko, V. P.: Vertical microalga flux in the Northern Laptev Sea (from the data collected by the yearlong sediment trap), Oceanology, 40, 801-808, 2000. 